(c) American Dairy Science Association, 2003.

\title{
Lactational Effect of Propionic Acid and Duodenal Glucose in Cows
}

\author{
S. Rigout, ${ }^{\star}$ C. Hurtaud, ${ }^{\star}$ S. Lemosquet, ${ }^{\star}$ A. Bach,† and H. Rulquin* \\ *Unité Mixte de Recherches Production du Lait, \\ Institut National de Recherche Agronomique, \\ 35590 Saint-Gilles, France \\ †Agribrands Europe \\ San Juan 189 \\ Barcelona, Spain
}

\section{ABSTRACT}

Five dairy cows were arranged in a $5 \times 5$ Latin square design to compare the effects of two amounts of either duodenal glucose or ruminal propionic acid (C3) on milk yield and composition. Treatments consisted of a grass silage-based diet supplemented with glucogenic nutrients either infused in the rumen as a mixture of volatile fatty acids (control) or pure C3 (1.72 and $3.45 \mathrm{Mcal} / \mathrm{d})$ or in the duodenum as glucose (1.72 and $3.45 \mathrm{Mcal} / \mathrm{d})$. Treatments were isoenergetic and isonitrogenous and contained 100 and $115 \%$ of energy and protein requirements according to INRA (1989), respectively. Only C3 treatments significantly modified ruminal volatile fatty acid composition and linearly increased C3 percentage (up to $25.5 \%$ ). Both treatments substantially decreased milk fat yield and content, and linearly increased milk and protein yields. Although no significant differences between glucose and C3 were highlighted for milk yield and composition, it seems that mechanisms involved in milk fat decrease are different. Indeed, whereas C3 treatments decreased fatty acid production in an homogeneous way, short- and long-chain fatty acids decreased and medium-chain fatty acid production increased with glucose treatments. A bibliographical study confirmed that increasing glucogenic precursors (GP) supply curvilinearly increase milk yield, linearly increase milk protein content (+ $0.04 \%$ per Mcal of GP) and curvilinearly decrease milk fat content $(-0.14 \%$ per Mcal of GP). Thus, it appears important to account for the nature of energy supplied by the ration in formulation.

(Key words: propionic acid, glucose, dairy cow, milk composition)

Received September 14, 2001.

Accepted December 9, 2001.

Corresponding author: Sophie Rigout; e-mail: rigout@st-gilles. rennes.inra.fr.
Abbreviation key: C3 = propionic acid, $\mathbf{G P}=$ glucogenic precursors, $\mathbf{P D I}=$ protein truly digested in the small intestine.

\section{INTRODUCTION}

Productive responses in ruminants are largely dependent on energy supply. The amount of energy as assessed by energy systems is the most important trait, but the nature of energetic materials supplied is also important for milk production in dairy cows. Glucose is essential for milk synthesis and an increase of its supply, especially when the dietary supply of glucose precursors is limiting, i.e., grass-silage diets, has been shown to enhance milk yield (Huhtanen et al., 1998; Hurtaud et al., 2000). A lot of energy has to be provided by diets in the form of propionic acid (C3) in the rumen or glucose in the intestine. The C3 can be supplied by favorable carbohydrate fermentation in the rumen, but an excessive ingestion of amounts of readily fermented carbohydrates or starch could lead to acidosis and laminitis (Owens et al., 1998). The amount of postruminal glucose can be increased by decreasing the part of starch fermented in the rumen with an appropriate starch processing, but this could alter total tract digestibility (Knowlton et al., 1998).

Many studies on the effect of a direct supply of glucose to the duodenum or the abomasum (Lemosquet et al., 1997; Oldick et al., 1997; Hurtaud et al., 1998a, 1998b) or C3 to the rumen (Hurtaud et al., 1998a) exist, but very few direct comparisons between these two precursors of glucose have been conducted (Hurtaud et al., 1998a; Hurtaud and Rulquin, 1999). With regard to literature results, the effects of infusions of C3 in the rumen or glucose in the duodenum have led to inconsistent results on milk production (Hurtaud et al., 2000). On the other hand, postruminal glucose (Lemosquet et al., 1997; Oldick et al., 1997; Hurtaud et al., 1998b) or ruminal C3 (Miettinen and Huhtanen, 1996; Huhtanen et al., 1998; Sheperd and Combs, 1998) seem to have similar effects on milk composition. Indeed, increasing 
their supply induces an increase of milk protein yield and a decrease of milk fat content and yield. However, the composition of milk fatty acids is different depending on the precursor supplied, so the decrease of milk fat may occur by different metabolic ways (Hurtaud et al., 1998a).

Thus, an experiment was conducted to compare the effect of graded amounts of duodenal glucose and ruminal C3 on milk yield and composition in dairy cows. Other measurements on glucose and AA metabolisms were carried on and will be the subject of a future study (Lemosquet et al., unpublished). The results were compared to literature results to define a dose-response curve of these two glucogenic materials on milk yield and composition and to know if it is interesting to optimize their supply by the ration.

\section{MATERIALS AND METHODS}

\section{Treatments and Experimental Design}

The experiment was conducted according to a $5 \times 5$ Latin square design with 14 -d periods ( $9 \mathrm{~d}$ of transition and adaptation and $5 \mathrm{~d}$ of measurement).

Treatments consisted of a control, two doses of glucose infused in the duodenum and two doses of C3 infused in the rumen. Treatments were formulated to be isoenergetic and isonitrogenous to compare the effect of energetic materials (i.e., glucose and C3) and to avoid the confounding effect of an increasing supply of energy. The control treatment consisted in a ruminal infusion of a VFA mixture: $14.6 \mathrm{~mol} / \mathrm{d}$ as $53.9 \%$ acetic acid, $20.4 \%$ of $\mathrm{C} 3$ and $25.6 \%$ of butyric acid (acetic and butyric acids: Merck S.A., Chelles, France; C3: Langlois S.A., Saint Jacques de la Lande, France). Such high concentrations of butyric acid were necessary to obtain a sufficient energetic concentration of the solution associated with a low molar concentration to prevent ruminal problems. The two glucose treatments consisted, respectively, of a ruminal infusion of the VFA mixture $(7.3 \mathrm{~mol} / \mathrm{d})$ plus a duodenal infusion of glucose $(618 \mathrm{~g} / \mathrm{d})$ or a duodenal infusion of pure glucose ( $1238 \mathrm{~g} / \mathrm{d}$; dextrose, Roquette, Lestrem, France). The two C3 treatments consisted in a ruminal infusion of the VFA mixture $(7.3 \mathrm{~mol} / \mathrm{d}) \mathrm{plus}$ C3 $(6.5 \mathrm{~mol} / \mathrm{d})$ or a ruminal infusion of pure C3 (13 $\mathrm{mol} / \mathrm{d})$.

To compare the effects of glucose and C3 on milk yield and composition, an energetic equivalence was adopted, assuming that glucose provides $2.75 \mathrm{Mcal}$ of $\mathrm{NE}_{\mathrm{L}} / \mathrm{kg}$ (Armstrong and Blaxter, 1961) and C3 0.266 Mcal of $\mathrm{NE}_{\mathrm{L}} / \mathrm{mol}$ (Institut National de la Recherche Agronomique, 1978). This equivalence corresponds to a molar equivalence of 1 mole of glucose for 1.86 mole of $\mathrm{C} 3$.

\section{Cows, Feeding, and Infusions}

Surgical preparation was reviewed and approved by the animal care committee of the French Ministry of Agriculture. The procedure was the same as described by Hurtaud et al. (1998b). Five duodenum- and rumenfistulated Holstein cows $(613 \pm 62 \mathrm{~kg}$ of BW, $32 \pm 4 \mathrm{~kg} /$ $\mathrm{d}$ of milk at $53 \pm 12 \mathrm{DIM}$ ) were used for the experiment. They were individually fed restricted amounts of a basal diet $58.6 \%$ big bale grass silage, $24.8 \%$ energy concentrate, $9.1 \%$ formaldehyde-treated soybean meal; DM basis) supplemented with minerals and vitamins (200 $\mathrm{g} / \mathrm{d}$ ) so that treatments (diet plus infusions) provide $100 \%$ of energy and $115 \%$ of protein requirements (Institut National de la Recherche Agronomique, 1989). Diets were also supplemented with $11 \mathrm{~g} / \mathrm{d}$ of L-Lys $\mathrm{HCl}$ (Ajinomoto Co. Inc., Tokyo, Japan) and 15 g/d of DLMet (Rhône-Poulenc, Commentry, France) according to the recommendations of Rulquin et al. (2001) to meet the requirement for the most limiting AA (Lys and Met) in dairy cows. The L-Lys $\mathrm{HCl}$ and DL-Met were dissolved with glucose in water and infused in the duodenum. Table 1 shows the chemical and nutrient composition of soybean meal, energy concentrate and grass silage and Table 2 shows the composition and nutritive value of the diets. Grass silage was fed three times per d $(25 \%$ at $0700 \mathrm{~h}, 25 \%$ at $1300 \mathrm{~h}, 50 \%$ at $1900 \mathrm{~h})$ and concentrate eight times a day in equal portions. Access to feed was limited to $1 \mathrm{~h}$ every $3 \mathrm{~h}$ from $0700 \mathrm{~h}$ onwards.

Each cow was continuously infused with three separate solutions: VFA mixture, C3 or water, and buffer in the rumen, and glucose or water in the duodenum (Table 3). The five infusions were isoenergetic and provided $3.45 \mathrm{Mcal} / \mathrm{d}$ (Table 3 ). The solutions were infused continuously by means of peristaltic pumps for $24 \mathrm{~h}$. A special device prevented direct contact between the ruminal wall and infused VFA.

\section{Measurements and Sampling}

The amounts of feed offered and refusals were measured daily. The DM content of grass silage was determined daily to adjust offered amounts.

Ruminal fluid was assayed for $\mathrm{pH}$, VFA, and ammonia on d 12 of each period. Individual samples were collected at $0.5,2.5,4.5,6.5,8.5$, and $10.5 \mathrm{~h}$ after morning milking. The $\mathrm{pH}$ was measured immediately. Then, after filtration through six layers of muslin, subsamples were composited to obtain a single daily pool for VFA and ammonia measurements. For VFA analysis, a preservative $\left(\mathrm{H}_{3} \mathrm{PO}_{4} 5 \% \mathrm{vol} / \mathrm{vol}+\mathrm{HgCl}_{2} 1 \% \mathrm{wt} / \mathrm{vol}\right)$ was added to one subsample ( $10 \% \mathrm{vol} / \mathrm{vol})$, and for ammonia analysis, another preservative ( $\mathrm{NaCl} 200 \% \mathrm{wt} / \mathrm{vol})$ was added to a second subsample ( $\mathrm{vol} / \mathrm{vol}$ ). The VFA concentrations were then determined by gas chromatography 
Table 1. Chemical composition and nutritive value of feedstuffs (DM basis).

\begin{tabular}{|c|c|c|c|c|c|c|c|c|c|}
\hline & $\mathrm{DM}$ & $\mathrm{CP}$ & $\mathrm{OM}$ & $\mathrm{ADF}$ & $\mathrm{NDF}$ & Starch & $\mathrm{EE}^{1}$ & Energy & $\mathrm{PDIE}^{2}$ \\
\hline & & & & \multicolumn{4}{|c|}{$\%$ of $\mathrm{DM}$} & (Mcal/kg) & $(\mathrm{g} / \mathrm{kg})$ \\
\hline Big bale grass silage & 55.5 & 15.4 & 90.7 & 29.9 & 56.3 & 2.2 & 2.5 & 1.70 & 83 \\
\hline Soybean $\mathrm{meal}^{3}$ & 87.8 & 51.3 & 92.5 & 8.1 & 17.8 & 5.6 & 2.9 & 2.01 & 385 \\
\hline Energy concentrate $^{4}$ & 88.6 & 11.3 & 92.0 & 13.1 & 32.7 & 37.4 & 5.1 & 1.70 & 101 \\
\hline \multicolumn{10}{|l|}{${ }^{1}$ Ether extract. } \\
\hline \multicolumn{10}{|c|}{${ }^{2}$ Protein truly digested in the small intestine delimited by energy supply. } \\
\hline \multicolumn{10}{|c|}{${ }^{3}$ Soybean meal spray-treated with $1 \%$ formaldehyde on an as fed basis. } \\
\hline${ }^{4}$ Contained $20 \%$ ba & y, 21.5 & whea & $37 \% \mathrm{~d}$ & aydrate & beet $\mathrm{pl}$ & $\mathrm{s}, 15 \%$ & & an, $2 \%$ & $\mathrm{rah} \mathrm{fe}_{\mathrm{c}}(\mathrm{ar}$ \\
\hline
\end{tabular}

(Hurtaud et al., 1998a) and ammonia concentrations by the reaction of Berthelot (Sahnoune et al., 1991) adapted to an auto-analyzer (Technicon, Domont, France).

Jugular blood was sampled on d 12 of each period at $0.5,2.5,4.5,6.5,8.5$, and $10.5 \mathrm{~h}$ after morning milking, using syringes containing heparin at 12 to $30 \mathrm{IU} / \mathrm{ml}$ (SMonovette, $7.5 \mathrm{ml}$; Sarstedt, Nümbrecht, Germany) for glucose (Bondar and Mead, 1974), acetate (Guynn and Veech, 1975), NEFA (Duncombe, 1964), $\beta$-hydroxybutyrate (McMurray et al., 1984), and total glycerides (Bucolo and David, 1973). Plasma metabolites were measured on a multiparameter analyzer (KONE Instruments Corporation, Espoo, Finland) using a KONE kit for glucose, a Biotrol kit (Biotrol Diagnostic, Chennevières les Louvres, France) for total glycerides and a Wako kit (Oxoid S.A., Dardilly, France) for NEFA determinations.

Cows were milked twice daily at 0630 and $1800 \mathrm{~h}$. Milk yield was recorded, and fat and protein contents were determined by infrared analysis (Milkoscan, Foss Electric, Hillerod, Denmark) at each milking. On d 13, $2 \mathrm{~L}$ of milk was taken from each cow at morning milking. Milk samples were stored at $-20^{\circ} \mathrm{C}$ for chemical analy- ses in the laboratory. Milk was analyzed for lactose, casein, fatty acids, soluble proteins ( $\alpha$-lactalbumin, $\beta$ lactoglobulin) according to Hurtaud et al. (1993), and milk metabolites (glucose-6-P, glycerol-3-P, 2-oxoglutarate, citrate, isocitrate, lactate and malate after milk deproteinization with $\mathrm{HClO}_{4}$, vol/vol) according to Hurtaud et al. (2000). The measurement of milk metabolites is interesting in the sense that their concentrations reflect their Golgi-vesicular and cytosolic levels (Faulkner, 1980).

\section{Statistical Analysis}

Daily milk yields during the last $7 \mathrm{~d}$ of each period were averaged for statistical analysis.

Each parameter was analyzed using PROC GLM of SAS (1990); cow, period, treatment and residual effects were the factors of variation. Results were expressed as least mean squares with standard errors of the means because of missing values for one period of one cow. VFA treatment was considered as control. Differences among treatment least mean squares were compared using the method of orthogonal polynomial contrasts. The contrast A was used to test linear effects of increas-

Table 2. Composition and nutritive value of the diets (DM basis).

\begin{tabular}{|c|c|c|c|c|c|}
\hline & \multirow[b]{2}{*}{ Control } & \multicolumn{2}{|c|}{ Glucose (Mcal/d) } & \multicolumn{2}{|c|}{$\mathrm{C} 3^{1}(\mathrm{Mcal} / \mathrm{d})$} \\
\hline & & 1.72 & 3.45 & 1.72 & 3.45 \\
\hline \multicolumn{6}{|l|}{ Diet (\% DM) } \\
\hline Grass silage & 53.5 & 55.8 & 55.2 & 54.7 & 55.2 \\
\hline Energy concentrate & 28.7 & 26.9 & 26.8 & 27.9 & 27.9 \\
\hline Soybean meal & 10.5 & 9.8 & 9.8 & 10.1 & 10.2 \\
\hline Minerals and vitamins & 1.21 & 1.14 & 1.13 & 1.19 & 1.16 \\
\hline Lysine & 0.07 & 0.06 & 0.06 & 0.07 & 0.06 \\
\hline Methionine & 0.09 & 0.09 & 0.09 & 0.09 & 0.09 \\
\hline $\mathrm{NE}_{\mathrm{L}},{ }^{2} \mathrm{Mcal} / \mathrm{kg}$ & 1.61 & 1.60 & 1.59 & 1.61 & 1.62 \\
\hline $\mathrm{CP}, \mathrm{g} / \mathrm{kg}$ & 18.1 & 17.9 & 17.8 & 18.0 & 18.1 \\
\hline $\mathrm{PDI}^{3} \mathrm{~g} / \mathrm{kg}$ & 115 & 113 & 112 & 114 & 115 \\
\hline
\end{tabular}


Table 3. Nature and composition of infusions in the rumen and duodenum, and $\mathrm{NE}_{\mathrm{L}}(\mathrm{Mcal} / \mathrm{d})$ supplied by infusions.

\begin{tabular}{|c|c|c|c|c|c|c|}
\hline & & \multirow[b]{2}{*}{ Control } & \multicolumn{2}{|c|}{ Glucose (Mcal/d) } & \multicolumn{2}{|c|}{$\mathrm{C} 3^{1}$ (Mcal/d) } \\
\hline & & & 1.72 & 3.45 & 1.72 & 3.45 \\
\hline & Vol. o & & & & & \\
\hline \multicolumn{7}{|c|}{ Site of infusion } \\
\hline Rumen & $40 \mathrm{~L}$ & $\mathrm{VFA}^{2}$ & $\mathrm{VFA}^{3}$ & -7 & $\mathrm{VFA}^{3}+\mathrm{C} 3^{4}$ & $\mathrm{C} 3^{5}$ \\
\hline Rumen & $10 \mathrm{~L}$ & Buffer $^{6}$ & Buffer $^{6}$ & Buffer $^{6}$ & Buffer $^{6}$ & Buffer $^{6}$ \\
\hline Duodenum & $10 \mathrm{~L}$ & $-^{7}$ & Glucose $^{8}$ & Glucose $^{9}$ & & $-^{7}$ \\
\hline \multicolumn{7}{|c|}{$\mathrm{NE}_{\mathrm{L}}$ supply $(\mathrm{Mcal} / \mathrm{d})$} \\
\hline VFA & & 3.45 & 1.73 & - & 1.73 & - \\
\hline C3 & & - & - & - & 1.72 & 3.45 \\
\hline Glucose & & - & 1.72 & 3.45 & - & - \\
\hline Total & & 3.45 & 3.45 & 3.45 & 3.45 & 3.45 \\
\hline
\end{tabular}

${ }^{1}$ Propionic acid.

${ }^{2} 14.6 \mathrm{~mol} / \mathrm{d}$ of VFA as $53.9 \%$ acetic acid, $20.4 \%$ propionic acid and $25.6 \%$ butyric acid.

$37.3 \mathrm{~mol} / \mathrm{d}$ of VFA.

${ }^{4} 6.5 \mathrm{~mol} / \mathrm{d}$ of propionic acid.

${ }^{5} 13 \mathrm{~mol} / \mathrm{d}$ of pure propionic acid.

${ }^{6} 707 \mathrm{~g}$ of $\mathrm{NaHCO}_{3}$ and $367 \mathrm{~g}$ of $\mathrm{KHCO}_{3}$.

${ }^{7}$ pure water.

${ }^{8} 618 \mathrm{~g} / \mathrm{d}$ of pure glucose.

${ }^{9} 1238 \mathrm{~g} / \mathrm{d}$ of pure glucose.

ing amounts of glucogenic materials whatever glucose or C3; the contrast B was used to test any difference between glucose and C3 in such a linear effect. The significance threshold was set at $P<0.05$ and the tendency threshold, at $P<0.10$, unless otherwise specified.

\section{RESULTS}

\section{Effect of Infusions on Intake and Digestive Parameters}

The control had an unexpectedly high level of feed refusal (Table 4). As a consequence of DMI, $\mathrm{NE}_{\mathrm{L}}$, and protein (protein truly digested in the small intestine [PDI] and CP) intakes increased linearly with increasing amounts of glucogenic materials. However, except for the control treatment, $\mathrm{NE}_{\mathrm{L}}$ and $\mathrm{PDI}$ intakes were comparable for the other treatments. The $\mathrm{NE}_{\mathrm{L}}$ balance was increased linearly $(P<0.01)$ by glucogenic materials, whereas no effect was observed on PDI balance.

Increasing the amounts of infused C3 linearly increased $(P<0.001)$ the percentage of ruminal C3 (from $17.1 \%$ for control treatment to $25.5 \%$ ) at the expense of ruminal acetic (from $66.7 \%$ for control treatment to $61.1 \%$ ) and butyric (from $12.6 \%$ for control treatment to 9.5\%) acids. Compared with control treatment, glucose treatments did not modify the percentage of acetic and propionic acids but slightly decreased butyric acid and increased isobutyric acid. Valeric acid increased linearly with increasing amounts of both glucogenic materials. The ratio of (acetic acid + butyric acid) to $\mathrm{C} 3$ remained unchanged with glucose treatments, whereas it decreased linearly from 4.67 to 2.80 with $\mathrm{C} 3$ treatments. Glucose had no significant effect on ruminal $\mathrm{pH}$, but $\mathrm{C} 3$ decreased ruminal $\mathrm{pH}$ for $3.45 \mathrm{Mcal} / \mathrm{d}$ infused. Treatments had no significant effect on total VFA and ammonia concentrations (Table 5).

\section{Milk Yield and Composition}

Milk yield tended to increase linearly $(P=0.09)$ with increasing amounts of glucogenic materials without significant difference between glucose and C3 (Table 6). Yields of milk, lactose, and protein increased or tended to increase linearly with increasing amounts of glucogenic materials up to $4 \%(P=0.09), 6 \%(P=0.01)$ and $7 \%$ $(P=0.07)$, respectively, without significant differences between glucose and C3 treatments. Lactose and protein contents and milk protein fractions (casein, $\alpha$-lactalbumin, and $\beta$-lactoglobulin) were unaffected (Table 6). Milk fat was more markedly modified than other milk parameters. Milk fat content was decreased linearly $(P<0.001)$ by glucose $(-0.39 \%)$ and by C3 $(-0.43 \%)$ treatments. Milk fat yield was also decreased linearly by glucose $(-5 \%)$ and $\mathrm{C} 3(-8 \%)$.

\section{Milk Metabolites}

Glucose and C3 treatments induced a linear $(P<$ 0.001 ) increase of glucose-6-P concentration in milk (Table 6). Concentrations of citrate, oxoglutarate, and malate decreased linearly with glucose and C3 treatments, 
Table 4. Effect of infusions of glucogenic materials on feed intake and nutrient balance.

\begin{tabular}{|c|c|c|c|c|c|c|c|c|}
\hline \multirow[b]{2}{*}{ Treatments } & \multirow[b]{2}{*}{ Control } & \multicolumn{2}{|c|}{ Glucose (Mcal/d) } & \multicolumn{2}{|c|}{$\mathrm{C} 3^{1}$ (Mcal/d) } & \multirow[b]{2}{*}{$\mathrm{SEM}^{2}$} & \multicolumn{2}{|c|}{ Contrast $^{3}$} \\
\hline & & 1.72 & 3.45 & 1.72 & 3.45 & & $\mathrm{~A}$ & B \\
\hline \multicolumn{9}{|l|}{$\operatorname{Diet}(\mathrm{kg} \mathrm{DM} / \mathrm{d})$} \\
\hline DMI & 15.6 & 16.6 & 16.7 & 16.0 & 16.3 & 0.22 & 0.011 & 0.288 \\
\hline Grass silage & 8.95 & 9.89 & 9.90 & 9.35 & 9.53 & 0.200 & 0.010 & 0.227 \\
\hline Energy concentrate & 4.76 & 4.75 & 4.78 & 4.73 & 4.80 & 0.029 & 0.382 & 0.640 \\
\hline Soybean meal & 1.74 & 1.75 & 1.76 & 1.72 & 1.76 & 0.012 & 0.276 & 1.000 \\
\hline Mineral-vitamin & 0.2 & 0.2 & 0.2 & 0.2 & 0.2 & - & & \\
\hline Lysine & 0.011 & 0.011 & 0.011 & 0.011 & 0.011 & - & & \\
\hline Methionine & 0.015 & 0.015 & 0.015 & 0.015 & 0.015 & - & & \\
\hline $\mathrm{NE}_{\mathrm{L}},{ }^{4} \mathrm{Mcal} / \mathrm{d}$ & 30.4 & 31.8 & 31.8 & 31.2 & 31.8 & 0.37 & 0.011 & 0.947 \\
\hline $\mathrm{NE}_{\mathrm{L}}$ Balance, $\%$ & 102 & 107 & 108 & 106 & 109 & 1.6 & 0.008 & 0.435 \\
\hline CP intake, g/d & 2830 & 2977 & 2987 & 2878 & 2933 & 39.2 & 0.014 & 0.317 \\
\hline $\mathrm{PDI},{ }^{5} \mathrm{~g} / \mathrm{d}$ & 1919 & 1998 & 2006 & 1942 & 1978 & 21.2 & 0.016 & 0.382 \\
\hline PDI balance, $\%$ & 121 & 121 & 121 & 121 & 120 & 1.8 & 0.939 & 0.758 \\
\hline
\end{tabular}

\footnotetext{
${ }^{1}$ Propionic acid.

${ }^{2}$ Standard error of the means. For the treatment of $1.72 \mathrm{Mcal} / \mathrm{d}$ of propionic acid infused (one missing cell), the SEM is $1.19 \times \mathrm{SEM}$ presented in the table.

${ }^{3}$ Contrast A: linear effect of increasing amount of glucogenic materials whatever duodenal glucose or ruminal propionic acid; Contrast B: difference between duodenal glucose and ruminal propionate in such a linear effect.

${ }^{4}$ Including infusions.

${ }^{5}$ Protein truly digested in the small intestine.
}

whereas concentration of isocitrate remained unchanged. Both glucogenic materials tended to increase $(P=0.05)$ milk concentration of glycerol-3-P and did not change milk lactate concentration (Table 6).

The ratios of lactose to glucose-6-P, and glycerol-3-P to glucose-6-P were decreased linearly by glucose and C3 treatments. The ratios of citrate, isocitrate, and oxoglutarate to glucose-6-P also decreased linearly with glucose and C3 treatments, whereas the ratios of isoci- trate to citrate and oxoglutarate to isocitrate remained unchanged (Table 6).

\section{Milk Fatty Acid Composition and Production}

The proportion and the production of even shortchain fatty acids $\left(\mathrm{C}_{4: 0}\right.$ to $\left.\mathrm{C}_{8: 0}\right)$ decreased linearly with increasing doses of glucogenic materials without difference between glucose and C3 treatments (Tables 7 and

Table 5. Effect of infusions of glucogenic materials on rumen $\mathrm{pH}$ and volatile fatty acid and ammonia concentrations.

\begin{tabular}{|c|c|c|c|c|c|c|c|c|}
\hline \multirow[b]{2}{*}{ Treatments } & \multirow[b]{2}{*}{ Control } & \multicolumn{2}{|c|}{ Glucose (Mcal/d) } & \multicolumn{2}{|c|}{$\mathrm{C} 3^{1}(\mathrm{Mcal} / \mathrm{d})$} & \multirow[b]{2}{*}{$\mathrm{SEM}^{2}$} & \multicolumn{2}{|c|}{ Contrast $^{3}$} \\
\hline & & 1.72 & 3.45 & 1.72 & 3.45 & & $\mathrm{~A}$ & $\mathrm{~B}$ \\
\hline VFA concentrations, $\mathrm{mol} / \mathrm{L}$ & 112.1 & 112.8 & 112.3 & 103.4 & 116.1 & 3.53 & 0.629 & 0.466 \\
\hline VFA, mol/100 mol & & & & & & & & \\
\hline Acetic & 66.7 & 67.0 & 67.7 & 63.8 & 61.1 & 0.33 & $<0.001$ & $<0.001$ \\
\hline Propionic & 17.1 & 17.6 & 17.1 & 21.2 & 25.5 & 0.20 & $<0.001$ & $<0.001$ \\
\hline Isobutyric & 0.59 & 0.67 & 0.74 & 0.66 & 0.60 & 0.016 & 0.002 & $<0.001$ \\
\hline Butyric & 12.6 & 11.6 & 10.8 & 11.0 & 9.5 & 0.34 & $<0.001$ & 0.017 \\
\hline Isovaleric & 1.43 & 1.42 & 1.61 & 1.62 & 1.45 & 0.115 & 0.498 & 0.360 \\
\hline Valeric & 1.18 & 1.40 & 1.58 & 1.38 & 1.57 & 0.051 & $<0.001$ & 0.945 \\
\hline Caproic & 0.34 & 0.40 & 0.49 & 0.37 & 0.32 & 0.046 & 0.274 & 0.023 \\
\hline Ratio $(\mathrm{C} 2+\mathrm{C} 4) / \mathrm{C} 3$ & 4.67 & 4.52 & 4.65 & 3.58 & 2.80 & 0.066 & $<0.001$ & $<0.001$ \\
\hline $\mathrm{pH}$ & 6.40 & 6.37 & 6.44 & 6.46 & 6.21 & 0.056 & 0.267 & 0.014 \\
\hline $\mathrm{NH}_{3}, \mathrm{mg} / \mathrm{L}$ & 57.6 & 56.0 & 68.7 & 59.8 & 52.9 & 7.35 & 0.729 & 0.156 \\
\hline
\end{tabular}

\footnotetext{
${ }^{1}$ Propionic acid.

${ }^{2}$ Standard error of the means. For the treatment of $1.72 \mathrm{Mcal} / \mathrm{d}$ of propionic acid infused (one missing cell), the SEM is $1.19 \times \mathrm{SEM}$ presented in the table.

${ }^{3}$ Contrast A: linear effect of increasing amount of glucogenic materials whatever duodenal glucose or ruminal propionic acid; Contrast B: difference between duodenal glucose and ruminal propionate in such a linear effect.
} 
Table 6. Effect of infusions of glucogenic materials on milk yield and composition and milk metabolites.

\begin{tabular}{|c|c|c|c|c|c|c|c|c|}
\hline \multirow[b]{2}{*}{ Treatments } & \multirow[b]{2}{*}{ Control } & \multicolumn{2}{|c|}{ Glucose (Mcal/d) } & \multicolumn{2}{|c|}{$\mathrm{C} 3^{1}(\mathrm{Mcal} / \mathrm{d})$} & \multirow[b]{2}{*}{$\mathrm{SEM}^{2}$} & \multicolumn{2}{|c|}{ Contrast $^{3}$} \\
\hline & & 1.72 & 3.45 & 1.72 & 3.45 & & $\mathrm{~A}$ & B \\
\hline Milk yield, kg/d & 25.2 & 26.3 & 26.8 & 26.0 & 25.9 & 0.51 & 0.090 & 0.257 \\
\hline \multicolumn{9}{|l|}{ Fat } \\
\hline$\%$ & 4.17 & 3.86 & 3.78 & 3.90 & 3.74 & 0.06 & $<0.001$ & 0.633 \\
\hline $\mathrm{g} / \mathrm{d}$ & 1050 & 1007 & 999 & 1009 & 965 & 21.1 & 0.023 & 0.277 \\
\hline $\mathrm{g} / \mathrm{d}$ & 764 & 809 & 818 & 775 & 804 & 19.0 & 0.068 & 0.610 \\
\hline Lactose, $\%$ & 4.97 & 5.01 & 4.95 & 5.03 & 4.96 & 0.029 & 0.572 & 0.796 \\
\hline Lactose, $\mathrm{g} / \mathrm{d}$ & 1246 & 1328 & 1352 & 1319 & 1318 & 23.8 & 0.011 & 0.334 \\
\hline Casein, $\mathrm{g} / \mathrm{kg}$ & 24.1 & 24.6 & 23.9 & 24.0 & 24.8 & 0.36 & 0.525 & 0.140 \\
\hline Casein/true protein, $\%$ & 79.1 & 79.5 & 77.9 & 80.1 & 79.6 & 1.53 & 0.845 & 0.458 \\
\hline$\alpha$-Lactalbumin, $\mathrm{g} / \mathrm{kg}$ & 1.51 & 1.48 & 1.55 & 1.57 & 1.50 & 0.029 & 0.562 & 0.254 \\
\hline$\beta$-Lactoglobulin, $\mathrm{g} / \mathrm{kg}$ & 4.55 & 4.48 & 4.65 & 4.68 & 4.84 & 0.140 & 0.278 & 0.375 \\
\hline Isocitrate & 0.248 & 0.223 & 0.239 & 0.220 & 0.225 & 0.024 & 0.595 & 0.672 \\
\hline Glycerol-3-P & 0.076 & 0.103 & 0.099 & 0.101 & 0.098 & 0.008 & 0.053 & 0.922 \\
\hline Malate & 0.223 & 0.133 & 0.120 & 0.149 & 0.125 & 0.012 & $<0.001$ & 0.778 \\
\hline Lactate & 0.155 & 0.184 & 0.211 & 0.183 & 0.190 & 0.036 & 0.321 & 0.687 \\
\hline \multicolumn{9}{|l|}{ Ratios $(\mathrm{mmol} / \mathrm{mmol})$} \\
\hline Lactose/glucose-6-P & 5124 & 4124 & 2937 & 4077 & 3234 & 432.2 & 0.007 & 0.638 \\
\hline Glycerol-3-P/glucose-6-P & 3.839 & 3.032 & 2.027 & 2.997 & 2.183 & 0.478 & 0.013 & 0.822 \\
\hline Citrate/glucose-6-P & 319.9 & 204.0 & 153.3 & 220.6 & 168.1 & 24.74 & 0.001 & 0.680 \\
\hline Isocitrate/citrate & 0.032 & 0.031 & 0.032 & 0.029 & 0.032 & 0.002 & 0.806 & 0.855 \\
\hline Isocitrate/glucose-6-P & 9.45 & 6.36 & 5.04 & 6.37 & 5.13 & 0.766 & $<0.001$ & 0.934 \\
\hline Oxoglutarate/isocitrate & 0.454 & 0.463 & 0.396 & 0.443 & 0.364 & 0.080 & 0.520 & 0.784 \\
\hline Oxoglutarate/glucose-6-P & 4.73 & 3.13 & 1.92 & 3.11 & 2.03 & 0.566 & 0.006 & 0.899 \\
\hline
\end{tabular}

${ }^{1}$ Propionic acid.

${ }^{2}$ Standard error of the means. For the treatment of $1.72 \mathrm{Mcal} / \mathrm{d}$ of propionic acid infused (one missing cell), the SEM is $1.19 \times \mathrm{SEM}$ presented in the table.

${ }^{3}$ Contrast A: linear effect of increasing amount of glucogenic materials whatever duodenal glucose or ruminal propionic acid; Contrast B: difference between duodenal glucose and ruminal propionate is such a linear effect.

8). The same trend occurred for the increase of even medium-chain fatty acids $\left(\mathrm{C}_{10: 0}\right.$ to $\left.\mathrm{C}_{14: 0}\right)$ as proportion, but their production tended to be different depending on the glucogenic material: a slight increase with glucose treatments and a linear decrease with C3 treatments. The $\mathrm{C}_{16}$ fatty acid group had a different response between glucose and C3 treatments: it increased linearly with glucose but not with C3 (contrast B: $P<0.01$ ). As a consequence, their production was unmodified with glucose but linearly decreased with C3 (contrast B: $P$ $<0.05$ ). On the contrary, $\mathrm{C}_{18}$ fatty acid group as proportion decreased linearly with glucose treatments but remained unchanged with $\mathrm{C} 3$ treatments (contrast B: $P$ $<0.01$ ). The percentage and production of trans $-\mathrm{C}_{18}$ fatty acid group decreased linearly with glucogenic materials without difference between glucose and C3 treatments. The percentage of unsaturated fatty acid group decreased slightly with glucose treatments, whereas it increased linearly with $\mathrm{C} 3$ treatments. The proportion and the production of odd short- $\left(\mathrm{C}_{5: 0}\right.$ to $\left.\mathrm{C}_{9: 0}\right)$ and medi- um- $\left(\mathrm{C}_{11: 0}\right.$ to $\left.\mathrm{C}_{15: 0}\right)$ chain fatty acids increased linearly with increasing amounts of glucogenic materials. However, the linear increase was greater for C3 than for glucose (contrast $\mathrm{B}: P<0.001$ ). The percentage of $\mathrm{C}_{17}$ fatty acid group remained unchanged with glucose treatments, whereas it increased linearly with C3 treatments. As a consequence, their production decreased linearly with glucose treatments, whereas it remained unchanged with $\mathrm{C} 3$ treatments. As a result for the glucose treatment, the decrease in fatty acid yield could be accounted for $80 \%$ by $\mathrm{C}_{18}$ fatty acids and for $17 \%$ by short-chain fatty acids. In contrast, for C3 treatments the decrease in milk fatty acid yield was constituted by similar decrease of short- and medium-chain fatty acids (27\%), $\mathrm{C}_{16}$ fatty acids group (38\%) and $\mathrm{C}_{18}$ fatty acids group $(35 \%)$.

\section{Plasma Metabolites}

Even though glucogenic materials tended to linearly increase plasma glucose concentration (Table 9, con- 
Table 7. Effect of infusions of glucogenic materials on milk fatty acid composition.

\begin{tabular}{|c|c|c|c|c|c|c|c|c|}
\hline \multirow[b]{2}{*}{ Treatments } & \multirow[b]{2}{*}{ Control } & \multicolumn{2}{|c|}{ Glucose (Mcal/d) } & \multicolumn{2}{|c|}{$\mathrm{C} 3^{1}(\mathrm{Mcal} / \mathrm{d})$} & \multirow[b]{2}{*}{$\mathrm{SEM}^{2}$} & \multicolumn{2}{|c|}{ Contrast $^{3}$} \\
\hline & & 1.72 & 3.45 & 1.72 & 3.45 & & $\mathrm{~A}$ & B \\
\hline \multicolumn{9}{|l|}{ Fatty acids, $\%$} \\
\hline $\mathrm{C}_{4: 0}$ & 2.67 & 2.47 & 2.28 & 2.44 & 2.24 & 0.064 & $<0.001$ & 0.674 \\
\hline $\mathrm{C}_{5: 0}$ & 0.017 & 0.023 & 0.020 & 0.028 & 0.042 & 0.003 & 0.005 & $<0.001$ \\
\hline $\mathrm{C}_{6: 0}$ & 2.23 & 2.08 & 1.97 & 2.03 & 1.90 & 0.042 & $<0.001$ & 0.312 \\
\hline $\mathrm{C}_{7: 0}$ & 0.017 & 0.027 & 0.029 & 0.029 & 0.049 & 0.003 & $<0.001$ & $<0.001$ \\
\hline $\mathrm{C}_{8: 0}$ & 1.48 & 1.46 & 1.44 & 1.39 & 1.38 & 0.024 & 0.025 & 0.145 \\
\hline $\mathrm{C}_{9: 0}$ & 0.029 & 0.047 & 0.053 & 0.047 & 0.085 & 0.005 & $<0.001$ & 0.001 \\
\hline $\mathrm{C}_{10: 0}$ & 3.50 & 3.69 & 3.78 & 3.39 & 3.59 & 0.071 & 0.056 & 0.082 \\
\hline $\mathrm{C}_{11: 0}$ & 0.048 & 0.089 & 0.099 & 0.096 & 0.168 & 0.011 & $<0.001$ & $<0.001$ \\
\hline $\mathrm{C}_{12 ; 0}$ & 4.00 & 4.50 & 4.74 & 4.00 & 4.42 & 0.091 & $<0.001$ & 0.029 \\
\hline $\mathrm{C}_{13: 0}$ & 0.085 & 0.123 & 0.135 & 0.134 & 0.206 & 0.008 & $<0.001$ & $<0.001$ \\
\hline $\mathrm{C}_{14: 1}$ & 1.17 & 1.40 & 1.41 & 1.25 & 1.39 & 0.047 & 0.003 & 0.743 \\
\hline $\mathrm{C}_{14: 0}$ & 13.2 & 13.6 & 13.6 & 13.1 & 13.3 & 0.20 & 0.361 & 0.429 \\
\hline iso- $_{15: 0}$ & 0.28 & 0.26 & 0.25 & 0.28 & 0.28 & 0.007 & 0.054 & 0.036 \\
\hline $\mathrm{C}_{15: 1}$ & 0.52 & 0.50 & 0.50 & 0.54 & 0.55 & 0.023 & 0.994 & 0.128 \\
\hline $\mathrm{C}_{15: 0}$ & 1.10 & 1.34 & 1.43 & 1.45 & 1.95 & 0.058 & $<0.001$ & $<0.001$ \\
\hline $\mathrm{C}_{16: 1}$ & 2.30 & 2.71 & 2.83 & 2.48 & 2.58 & 0.126 & 0.025 & 0.180 \\
\hline $\mathrm{C}_{16: 0}$ & 37.8 & 38.9 & 39.7 & 38.4 & 37.1 & 0.517 & 0.407 & 0.004 \\
\hline iso- $\mathrm{C}_{17: 0}$ & 0.33 & 0.31 & 0.30 & 0.35 & 0.33 & 0.014 & 0.302 & 0.148 \\
\hline $\mathrm{C}_{17: 1}$ & 0.74 & 0.72 & 0.72 & 0.81 & 0.81 & 0.022 & 0.314 & 0.016 \\
\hline $\mathrm{C}_{17: 0}$ & 0.55 & 0.54 & 0.54 & 0.62 & 0.68 & 0.018 & 0.013 & $<0.001$ \\
\hline $\mathrm{C}_{18: 2}$ & 1.58 & 1.57 & 1.53 & 1.55 & 1.65 & 0.030 & 0.769 & 0.017 \\
\hline $\mathrm{C}_{18: 3}$ & 0.48 & 0.49 & 0.49 & 0.45 & 0.50 & 0.027 & 0.680 & 0.834 \\
\hline $\mathrm{C}_{18: 1}$ & 15.5 & 14.5 & 14.2 & 15.5 & 16.0 & 0.34 & 0.368 & 0.004 \\
\hline trans $-10 \mathrm{C}_{18: 1}$ & 0.77 & 0.69 & 0.65 & 0.71 & 0.70 & 0.021 & 0.003 & 0.081 \\
\hline trans $-11 \mathrm{C}_{18: 1}$ & 1.37 & 1.30 & 1.24 & 1.33 & 1.26 & 0.051 & 0.086 & 0.746 \\
\hline $\mathrm{C}_{18: 0}$ & 8.19 & 6.77 & 6.06 & 7.53 & 6.91 & 0.330 & 0.001 & 0.098 \\
\hline \multicolumn{9}{|l|}{ Fatty acids, $\%$} \\
\hline $\mathrm{C}_{4: 0}$ to $\mathrm{C}_{8: 0}$ & 6.38 & 6.02 & 5.68 & 5.86 & 5.53 & 0.119 & $<0.001$ & 0.374 \\
\hline $\mathrm{C}_{5: 0}$ to $\mathrm{C}_{9: 0}$ & 0.063 & 0.097 & 0.102 & 0.105 & 0.175 & 0.010 & $<0.001$ & $<0.001$ \\
\hline $\mathrm{C}_{10: 0}$ to $\mathrm{C}_{14}$ & 21.9 & 23.2 & 23.5 & 21.8 & 22.7 & 0.34 & 0.013 & 0.135 \\
\hline $\mathrm{C}_{11: 0}$ to $\mathrm{C}_{15: 0}$ & 2.04 & 2.30 & 2.41 & 2.50 & 3.15 & 0.069 & $<0.001$ & $<0.001$ \\
\hline $\mathrm{C}_{16: 0}+\mathrm{C}_{16: 1}$ & 40.2 & 41.6 & 42.6 & 40.9 & 39.6 & 0.59 & 0.219 & 0.005 \\
\hline iso- $\mathrm{C}_{17: 0}+\mathrm{C}_{17: 1}+\mathrm{C}_{17: 0}$ & 1.62 & 1.57 & 1.56 & 1.78 & 1.82 & 0.047 & 0.236 & 0.003 \\
\hline $\mathrm{C}_{18: 2}+\mathrm{C}_{18: 3}+\mathrm{C}_{18: 1}+\mathrm{C}_{18: 0}$ & 25.7 & 23.3 & 22.3 & 25.1 & 25.0 & 0.57 & 0.013 & 0.007 \\
\hline $\mathrm{C}_{18: 1}($ trans $-10+$ trans -11$)$ & 2.14 & 1.99 & 1.88 & 2.04 & 1.96 & 0.068 & 0.026 & 0.425 \\
\hline Odd, \% & 3.72 & 3.97 & 4.08 & 4.38 & 5.14 & 0.109 & $<0.001$ & $<0.001$ \\
\hline Unsaturated, \% & 24.4 & 23.8 & 23.6 & 24.6 & 25.4 & 0.42 & 0.880 & 0.011 \\
\hline
\end{tabular}

\footnotetext{
${ }^{1}$ Propionic acid.

${ }^{2}$ Standard error of the means. For the treatment of $1.72 \mathrm{Mcal} / \mathrm{d}$ of propionic acid infused (one missing cell), the SEM is $1.19 \times \mathrm{SEM}$ presented in the table.

${ }^{3}$ Contrast A: linear effect of increasing amount of glucogenic materials whatever duodenal glucose or ruminal propionic acid; Contrast B: difference between duodenal glucose and ruminal propionate in such a linear effect.
}

trast A: $P=0.06)$, the evolution of plasma glucose was different between glucose and C3 treatments (contrast B: $P<0.05)$. Indeed, glucose treatments linearly increased plasma glucose concentration by $6.6 \mathrm{mg} / 100$ $\mathrm{ml}$, whereas $\mathrm{C} 3$ treatments had no effect. Plasma concentrations of acetate and BHBA decreased linearly by $50 \%$ with glucogenic materials. Plasma NEFA concentrations decreased linearly with both treatments. With C3 infusions, NEFA concentrations decreased significantly only for the highest dose of $\mathrm{C} 3$, mainly due to a lower value measured in one cow. Plasma total glyceride concentrations decreased linearly without difference between glucose and C3.

\section{DISCUSSION}

\section{Effects of Glucose and C3 Infusions on Milk Yield and Composition}

Linear responses of milk production and composition were obtained with increasing amounts of glucogenic materials. Glucose and C3 substantially decreased milk fat yield and content and increased in a lesser extent milk, lactose, and protein yields. However, no difference between glucose and C3 could have been highlighted in the tested range of glucogenic materials amounts.

To avoid a confounding effect between the level of energy supply and changes in the nature of materials 
RIGOUT ET AL.

Table 8. Effect of infusions of glucogenic materials on milk fatty acid production.

\begin{tabular}{|c|c|c|c|c|c|c|c|c|}
\hline \multirow[b]{2}{*}{ Treatments } & \multirow[b]{2}{*}{ Control } & \multicolumn{2}{|c|}{ Glucose (Mcal/d) } & \multicolumn{2}{|c|}{$\mathrm{C} 3^{1}(\mathrm{Mcal} / \mathrm{d})$} & \multirow[b]{2}{*}{$\mathrm{SEM}^{2}$} & \multicolumn{2}{|c|}{ Contrast $^{3}$} \\
\hline & & 1.72 & 3.45 & 1.72 & 3.45 & & $\mathrm{~A}$ & $\mathrm{~B}$ \\
\hline \multicolumn{9}{|l|}{ Fatty acids, g/d } \\
\hline $\mathrm{C}_{4: 0}$ to $\mathrm{C}_{8: 0}$ & 58.2 & 52.4 & 49.1 & 50.8 & 46.0 & 1.95 & 0.001 & 0.276 \\
\hline $\mathrm{C}_{5: 0}$ to $\mathrm{C}_{9: 0}$ & 0.57 & 0.82 & 0.86 & 0.89 & 1.41 & 0.078 & $<0.001$ & $<0.001$ \\
\hline $\mathrm{C}_{10: 0}$ to $\mathrm{C}_{14}$ & 199 & 203 & 204 & 189 & 189 & 5.5 & 0.784 & 0.075 \\
\hline $\mathrm{C}_{11: 0}$ to $\mathrm{C}_{15: 0}$ & 18.3 & 19.8 & 20.5 & 21.7 & 25.8 & 0.57 & $<0.001$ & $<0.001$ \\
\hline $\mathrm{C}_{16: 0}+\mathrm{C}_{16: 1}$ & 360 & 357 & 363 & 353 & 329 & 9.5 & 0.241 & 0.027 \\
\hline iso- $\mathrm{C}_{17: 0}+\mathrm{C}_{17: 1}+\mathrm{C}_{17: 0}$ & 14.6 & 13.6 & 13.3 & 15.5 & 15.0 & 0.43 & 0.422 & 0.021 \\
\hline $\mathrm{C}_{18: 2}+\mathrm{C}_{18: 3}+\mathrm{C}_{18: 1}+\mathrm{C}_{18: 0}$ & 233 & 202 & 192 & 219 & 208 & 6.5 & 0.002 & 0.112 \\
\hline trans $-10 \mathrm{C}_{18: 1}+$ trans $-11 \mathrm{C}_{18: 1}$ & 19.2 & 17.2 & 16.1 & 17.7 & 16.2 & 0.64 & 0.003 & 0.925 \\
\hline Odd, g/d & 33.5 & 34.2 & 34.7 & 38.1 & 42.2 & 0.94 & 0.001 & $<0.001$ \\
\hline Unsaturated, g/d & 220 & 206 & 201 & 215 & 211 & 4.9 & 0.038 & 0.194 \\
\hline
\end{tabular}

${ }^{1}$ Propionic acid.

${ }^{2}$ Standard error of the means. For the treatment of $1.72 \mathrm{Mcal} / \mathrm{d}$ of propionic acid infused (one missing cell), the SEM is $1.19 \times$ SEM presented in the table.

${ }^{3}$ Contrast A: Linear effect of increasing amount of glucogenic materials whatever duodenal glucose or ruminal propionic acid; Contrast B: difference between duodenal glucose and ruminal propionate in such a linear effect.

supplied in the experiment, isoenergetic treatments were used to compare graded amounts of duodenal glucose and ruminal C3 infusions. However, feed intake was depressed with the VFA infusion for the control treatment (Table 4). A decrease in feed DMI has already been observed with increasing infusions of VFA in the rumen (Faverdin et al., 1992) and with ruminal butyrate infusion (Huhtanen et al., 1998). Thus, the decrease of feed DMI could be due to the high percentage of butyric acid (25.6\%) infused in the rumen. Consequently, the control treatment provided slightly less energy supply than the other treatments, and this could have softened the conclusions of the experiment.

Similar experiments from literature with glucose infusion (Lemosquet et al., 1997; Oldick et al., 1997; Hurtaud et al., 1998a, 1998b, 2000; Hurtaud and Rulquin, 1999) led to inconsistent results, as mentioned by Hurtaud et al. (2000). This may arise from the variability of postruminal starch amount in control treatments and could be accounted for considering postruminal supply of "bypass" starch plus glucose infusion (Hurtaud et al., 2000). Our present results fit well with literature data with a curvilinear increase of milk $\left(\mathrm{R}^{2}=0.58\right)$ and protein $\left(R^{2}=0.85\right)$ yields and a linear decrease of milk fat yield and content $\left(R^{2}=0.70\right)$.

Results from C3 infusion in the literature (Miettinen and Huhtanen, 1996; Huhtanen et al., 1998; Hurtaud et al., 1998a; Sheperd and Combs, 1998; Hurtaud and Rulquin, 1999) lead to an increase of milk and protein yield and a decrease of milk fat yield when mean doses were infused (Miettinen and Huhtanen, 1996; Huhtanen et al., 1998; Hurtaud et al., 1998a; Hurtaud and Rulquin, 1999), and no effect on milk yield with great doses infused (Sheperd and Combs, 1998). Here again, differences between experiments in the composition of basal diet may have affected ruminal C3 supply and accounted for the differences in responses to extra C3. Indeed, when expressed on the basis of the percentage

Table 9. Effect of infusions of glucogenic materials on blood metabolites.

\begin{tabular}{|c|c|c|c|c|c|c|c|c|}
\hline \multirow[b]{2}{*}{ Treatments } & \multirow[b]{2}{*}{ Control } & \multicolumn{2}{|c|}{ Glucose (Mcal/d) } & \multicolumn{2}{|c|}{$\mathrm{C}^{1}(\mathrm{Mcal} / \mathrm{d})$} & \multirow[b]{2}{*}{$\mathrm{SEM}^{2}$} & \multicolumn{2}{|c|}{ Contrast $^{3}$} \\
\hline & & 1.72 & 3.45 & 1.72 & 3.45 & & $\mathrm{~A}$ & $\mathrm{~B}$ \\
\hline Glucose, $\mathrm{mg} / 100 \mathrm{ml}$ & 64.1 & 65.7 & 70.7 & 60.9 & 65.1 & 1.46 & 0.057 & 0.021 \\
\hline $\mathrm{NEFA}, \mu \mathrm{mol} / \mathrm{L}$ & 101.2 & 76.7 & 73.0 & 89.2 & 76.4 & 6.78 & 0.009 & 0.728 \\
\hline Acetate, $\mathrm{mg} / 100 \mathrm{ml}$ & 9.0 & 5.6 & 5.0 & 6.1 & 5.7 & 0.53 & $<0.001$ & 0.348 \\
\hline BHBA, mg/100 ml & 8.3 & 5.2 & 4.0 & 5.0 & 4.1 & 0.37 & $<0.001$ & 0.938 \\
\hline Total glycerides, mg/L & 75.3 & 59.2 & 61.0 & 72.7 & 65.5 & 4.20 & 0.040 & 0.463 \\
\hline
\end{tabular}

\footnotetext{
${ }^{1}$ Propionic acid.

${ }^{2}$ Standard error of the means. For the treatment of $1.72 \mathrm{Mcal} / \mathrm{d}$ of propionic acid infused (one missing cell), the SEM is $1.19 \times \mathrm{SEM}$ presented in the table.

${ }^{3}$ Contrast A: linear effect of increasing amount of glucogenic materials whatever duodenal glucose or ruminal propionic acid; Contrast B: difference between duodenal glucose and ruminal propionate in such a linear effect.
} 
of total C3 in the rumen, responses in milk yield fit an increasing curvilinear curve $\left(\mathrm{R}^{2}=0.53\right)$, milk protein yield shows an increasing linear relationship $\left(\mathrm{R}^{2}=\right.$ $0.74)$, and milk fat yield and content fit a linear decrease $\left(\mathrm{R}^{2}=0.89\right)$.

However, such "classical" observations did not allow either direct comparisons between glucose and C3 nor account for concomitant variations or differences in C3 and glucose. In that way, we tried to assess the amount of energy provided by glucogenic precursors (GP) available from the rumen and the intestine, using the following equations:

$\begin{aligned} \text { Rumen GP }(\mathrm{Mcal} / \mathrm{d})= & \left(\mathrm{FOM} \times 9 \times \% \mathrm{C}_{\text {rum }}+\mathrm{C} 3_{\text {inf }}\right) \times \\ 0.266 & \\ & \end{aligned}$

where FOM $\times 9$ (moles/d) is the amount of VFA produced per gram of fermentable OM (Sauvant et al., 1996), \% $3_{\text {Rum }}$ the percentage of $\mathrm{C} 3$ in the rumen, Starch $_{\mathrm{ID}} \times$ dig. $(\mathrm{kg} / \mathrm{d})$ is the amount of intestinal glucose provided by the diet and calculated using the Dutch tables of Centraal Veevoederbureau (1995), $\mathrm{G}_{\mathrm{inf}}(\mathrm{kg} / \mathrm{d})$ and $\mathrm{C} 3_{\text {inf }}$ are respectively the amount of glucose infused in the duodenum and $\mathrm{C} 3$ infused in the rumen and assuming that $1 \mathrm{~kg}$ of glucose provides $2.75 \mathrm{Mcal}$ (Armstrong and Blaxter, 1961), and 1 mole of C3 provides $0.266 \mathrm{Mcal}$ (Institut National de la Recherche Agronomique, 1978).

Data from 10 experiments (Miettinen and Huhtanen, 1996; Lemosquet et al., 1997; Oldick et al., 1997; Huhtanen et al, 1998; Hurtaud et al., 1998a, 1998b, 2000; Sheperd and Combs, 1998; Hurtaud and Rulquin, 1999) were analyzed against each fraction or total GP accounting also for intertrials effects (possibly linked to cows and experiment characteristics). It appears that we were still unable to detect any differences between glucose and C3, but indeed it does not mean that differences does not exist. In summary, milk yield increased by $0.2 \mathrm{~kg} / \mathrm{d}$ when $1 \mathrm{Mcal} / \mathrm{d}$ of energy intake is substituted by GP (Figure 1). The relationship is curvilinear but the increase has a limited extent. For milk fat yield and content, $1 \mathrm{Mcal}$ of GP ingested leads to a curvilinear decrease of $0.14 \%$ of fat. Milk fat content unexpectedly decreased at a slower rate for great GP supply. Moreover, C3 may decrease milk fat content more markedly than glucose. Milk protein content is increased linearly by $0.035 \%$ by $1 \mathrm{Mcal}$ of GP.

\section{Mechanisms of Milk Fat Decrease}

The mechanisms of milk fat depression are different between duodenal glucose and ruminal C3. The C3
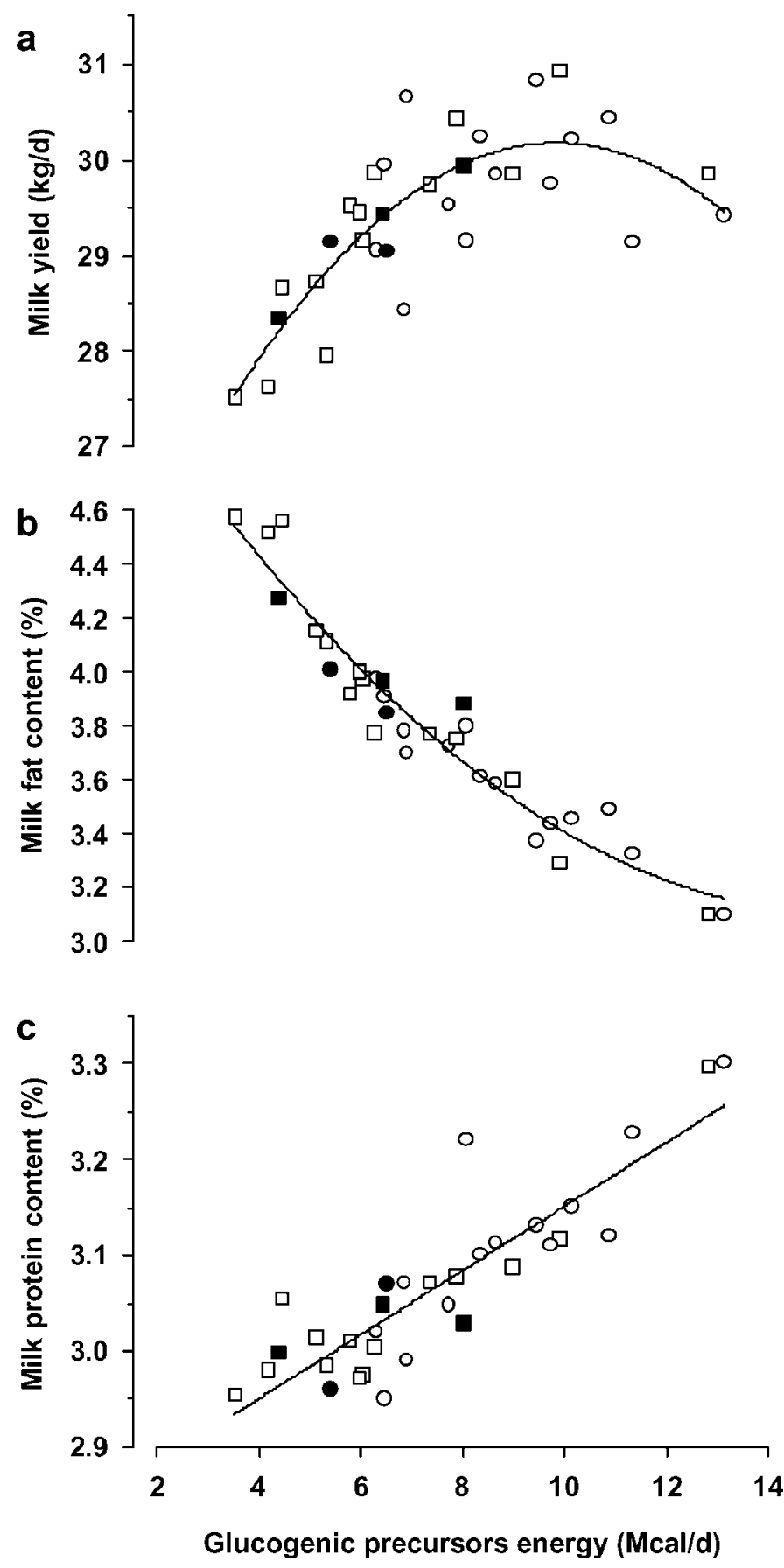

Figure 1. Effect of the amount of energy provided by glucogenic precursors (GPE) available from the rumen and the intestine on milk yield (a), milk fat (b) and milk protein contents (c). Data of the present experiment ( propionic acid treatments; $\square$ : glucose treatments) were compared with literature data $(\bigcirc$ : Hurtaud et al., 1998ab; Hurtaud et al., 2000; Hurtaud and Rulquin, 1999; Lemosquet et al., 1997; Oldick et al., 1997 for glucose treatments and $\square$ : Huhtanen et al., 1998; Hurtaud et al., 1998a; Hurtaud and Rulquin, 2000; Miettinen and Huhtanen, 1996; Sheperd et al., 1998 for propionic acid treatments). Regression equations: Milk yield $(\mathrm{kg} / \mathrm{d})=23.8+1.3 \times$ [GPE] $-0.07 \times[\mathrm{GPE}]^{2}\left(\mathrm{R}^{2}=0.99 ; \mathrm{SEM}=0.62 ; P<0.001\right) ;$ Milk fat content $(\%)=5.5-0.3 \times[\mathrm{GPE}]+0.01 \times[\mathrm{GPE}]^{2}\left(\mathrm{R}^{2}=0.93 ; \mathrm{SEM}=0.13 ; P<\right.$ $0.001)$; Milk protein content $(\%)=2.8+0.035 \times[\mathrm{GPE}]\left(\mathrm{R}^{2}=0.96\right.$; SEM $=0.05 ; P<0.001)$. 
treatments decreased milk fatty acid production homogeneously whatever the length of fatty acid chain (except the increased production of odd fatty acids). In contrast, for glucose treatments, the production of even short- and long-chain fatty acids decreased linearly and the production of medium-chain fatty acids increased. As a result, the profile of fatty acid percentage remained unchanged with C3 treatments compared with glucose treatments for which the percentage of short- and longchain fatty acids decreased and that of medium-chain fatty acids slightly increased.

The decrease in even short-chain fatty acids resulted from the linear decrease of plasma concentrations of their precursors. In the case of C3 treatments, the decrease of plasma concentrations of acetate and BHBA could be a consequence of the modification of VFA profile in the rumen (Huhtanen et al., 1993). For glucose treatments, the decrease of plasma concentrations of acetate and BHBA cannot be explained by the same phenomenon: the ratio of (acetic acid + butyric acid) to $\mathrm{C} 3$ and ruminal acidity remained unchanged (Table 5). On the other hand, glucose itself could have decreased plasma acetate and BHBA, as previously observed (Storry and Rook, 1965).

The increase in de novo synthesis of medium-chain fatty acids could be due to a possible lower inhibition of acetyl CoA carboxylase (Palmquist et al., 1993) for glucose treatments and favored by a greater supply of NADPH for both glucogenic materials. A part of the increased amount of glucose-6-P could have been utilized to provide energy because it was not fully utilized for lactose and glycerol-3-P syntheses, as stated by the linear decrease of the ratio of lactose and glycerol-3-P to glucose-6-P (Table 6). The Krebs cycle could not have provided a greater supply of energy because milk concentrations of citrate, oxoglutarate, and malate and their ratios to glucose-6-P decreased linearly (Table 6). However, a part of glucose-6-P could have provided energy through the pentose phosphate pathway. For C3 treatments, the total amount of C3 infused is not converted in glucose through gluconeogenesis (Brockman, 1993). Indeed, a part of C3 is taken up by the udder (Laarveld et al., 1981) and utilized for odd fatty acids synthesis (Massart-Leen et al., 1983). Moreover, plasma concentrations of glucose remained unchanged and plasma concentrations of acetate decreased, suggesting that compared to glucose treatments, fewer energetic substrates (glucose and acetate) were provided to the mammary gland; this could explain the lesser extent of de novo synthesis of fatty acids with C3 than with glucose.

The main difference between glucose and C3 treatments lies in the linear decrease of long-chain fatty acids percentage with glucose and its constancy with
C3. The decrease in the production of long-chain fatty acids observed for glucose and C3 treatments resulted from a linear decrease of plasma concentrations of NEFA and total glycerides. For glucose treatments, these decreased plasma concentrations could be related to a decrease in the balance lipolysis/lipogenesis (Griinari et al., 1997) and may be caused by a sufficient supply of energetic substrate (i.e., glucose) to the mammary gland contrary to C3 treatments.

\section{CONCLUSIONS}

In this study, duodenal infusions of glucose and ruminal infusions of C3 decreased milk fat yield and content and increased milk and milk protein yields to a lesser extent. However, the increase in milk yield suggests that glucogenic material supply is insufficient with grass silage-based diets to ensure maximal milk yield when energy and protein supplies meet the requirements. The bibliographical study showed that increasing GP supply leads to a curvilinear increase in milk yield, a linear increase of milk protein content $(+0.04 \%$ per Mcal of GP) and a curvilinear decrease of milk fat content $(-0.14 \%$ per Mcal of GP).

Neither the present experiment nor the bibliographical study demonstrated any differences between glucose and C3. However, differences between glucose and C3 exist in mechanisms involved in milk fat depression (i.e., differences in milk fatty acid composition) and could exist in mechanisms involved in milk protein increase. Nevertheless, it appears important in formulation to account for the nature of energetic material supplied by the ration.

\section{ACKNOWLEDGMENTS}

The authors gratefully thank P. Lamberton and his team for their helpful assistance, care and feeding of cows; and M. Texier, T. Le Mouel, I. Jicquel, S. Rigault, M. Ermel and M. Vérité for technical assistance; and $R$. Vérité for fruitful discussions in the preparation of this manuscript.

\section{REFERENCES}

Armstrong, D. G., and K. L. Blaxter. 1961. The utilization of energy of carbohydrate by ruminants. Pages 187-199 in Proc. 2nd Symp. Energy Metab. Eur. Assoc. Anim. Prod., Wageningen, The Netherlands.

Bondar, R. J., and D. C. Mead. 1974. Evaluation of glucose-6-phosphate dehydrogenase from Leuconostoc mesenteroides in the hexokinase method for determining glucose in serum. Clin. Chem. 20:586-590.

Brockman, R. P. 1993. Glucose and short-chain fatty acid metabolism. Pages 249-265 in Quantitative Aspects of Ruminant Digestion and Metabolism. J. M. Forbes and J. France, ed. CAB International, Wallingford, UK. 
Bucolo, G., and H. David. 1973. Quantitative determination of serum triglycerides by the use of enzymes. Clin. Chem. 19:476-482.

Centraal Veevoederbureau. 1995. Veevoedertabel. Chemical Composition, Digestibility and Feeding Value of Feedstuffs (in Dutch). Lelystad, The Netherlands.

Duncombe, W. G. 1964. The colorimetric micro-determination of nonesterified fatty acids in plasma. Clin. Chem. Acta 9:122.

Faulkner, A. 1980. The presence of cellular metabolites in milk. Biochim. Biophys. Acta 630:141-145.

Faverdin, P., B. Richou, and J. L. Peyraud. 1992. Effects of digestive infusions of volatile fatty acids or glucose on food intake in lactating or dry cows. Ann. Zootech. 41:93.

Griinari, J. M., M. A. McGuire, D. A. Dwyer, D. E. Bauman, and D. L. Palmquist. 1997. Role of insulin in the regulation of milk fat synthesis in dairy cows. J. Dairy Sci. 80:1076-1084.

Guynn, R. W., and R. L. Veech. 1975. Enzymatic determination of acetate. Meth. Enzym. 35:302-307.

Huhtanen, P., R. Blauwiekel, and I. Saastamoinen. 1998. Effects of intraruminal infusions of propionate and butyrate with two different protein supplements on milk production and blood metabolites in dairy cows receiving grass silage-based diet. J. Sci. Food Agric. 77:213-222.

Huhtanen, P., H. Miettinen, and M. Ylinen. 1993. Effect of increasing ruminal butyrate on milk yield and blood constituents in dairy cows fed a grass silage-based diet. J. Dairy Sci. 76:1114-1124.

Hurtaud, C., S. Lemosquet, and H. Rulquin. 2000. Effect of graded duodenal infusions of glucose on yield and composition of milk from dairy cows. 2. Diets based on grass silage. J. Dairy Sci. 83:2952-2962.

Hurtaud, C., and H. Rulquin. 1999. Effect of the nature of energy source (propionic acid, glucose or starch) on milk yield and composition in dairy cows [French]. Renc. Rech. Ruminants 6:103106 (Abstr.).

Hurtaud, C., H. Rulquin, and R. Vérité. 1993. Effect of infused volatile fatty acids and caseinate on milk composition and coagulation in dairy cows. J. Dairy Sci. 76:3011-3020.

Hurtaud, C., H. Rulquin, and R. Vérité. 1998b. Effects of graded duodenal infusions of glucose on yield and composition of milk from dairy cows. 1. Diets based on corn silage. J. Dairy Sci. 81:3239-3247.

Hurtaud, C., H. Rulquin, and R. Vérité. 1998a. Effects of level and type of energy source (volatile fatty acids or glucose) on milk yield, composition and coagulating properties in dairy cows. Reprod. Nutr. Dev. 38:315-330.

Institut National de la Recherche Agronomique. 1978. Utilisation énergétique des produits terminaux de la digestion. Pages $47-$ 88 in Alimentation Des Ruminants. R. Jarrige, ed. INRA publications, Versailles, France.
Jarrige, R., ed. 1989. Ruminant Nutrition. Recommended Allowances and Feed Tables. John Libbey, Eurotext, London, England.

Knowlton, K. F., B. P. Glenn, and R. A. Erdman. 1998. Performance, ruminal fermentation, and site of starch digestion in early lactation cows fed corn grain harvested and processed differently. J. Dairy Sci. 81:1972-1984.

Laarveld, B., D. A. Christensen, and R. P. Brockman. 1981. The effect of insulin on net metabolism of glucose and amino acids by the bovine mammary gland. Endocrinology 108:2217-2221.

Lemosquet, S., N. Rideau, H. Rulquin, P. Faverdin, J. Simon, and R. Vérité. 1997. Effects of a duodenal glucose infusion on the relationship between plasma concentrations of glucose and insulin in dairy cows. J. Dairy Sci. 80:2854-2865.

Massart-Leen, A. M., E. Roets, G. Peeters, and R. Verbeke. 1983 Propionate for fatty acid synthesis by the mammary gland of the lactating goat. J. Dairy Sci. 66:1445-1454.

McMurray, C. H., W. J. Blanchflower, and D. A. Rice. 1984. Automated kinetic method for D-3-hydroxybutyrate in plasma or serum. Clin. Chem. 30:421-425.

Miettinen, H., and P. Huhtanen. 1996. Effects of the ratio of ruminal propionate to butyrate on milk yield and blood metabolites in dairy cows. J. Dairy Sci. 79:851-861.

Oldick, B. S., C. R. Staples, W. W. Thatcher, and P. Gyawu. 1997. Abomasal infusion of glucose and fat effect on digestion, production, and ovarian and uterine functions of cows. J. Dairy Sci. 80:1315-1328.

Owens, F. N., D. S. Secrist, W. J. Hill, and D. R. Gill. 1998. Acidosis in cattle: a review. J. Anim. Sci. 76:275-286.

Palmquist, D. L., A. D. Beaulieu, and D. M. Barbano. 1993. Feed and animal factors influencing milk fat composition. J. Dairy Sci. 76:1753-1771.

Rulquin, H., R. Vérité, and J. Guinard-Flament. 2001. Amino acids truly digestible in the small intestine: the AADI system for the dairy cow [French]. INRA Prod. Anim. 14:265-274.

Sahnoune, S., J. M. Besle, M. Chenost, J. P. Jouany, and D. Combes. 1991. Treatment of straw with urea. 1. Ureolysis in a low water medium. Anim. Feed Sci. Technol. 34:75-93.

SAS User's Guide: Statistics. Version 6 Edition 4. 1990. SAS Inst., Inc., Cary, NC.

Sauvant, D., R. Baumont, and P. Faverdin. 1996. Development of a mechanistic model of intake and chewing activities of sheep. J. Anim. Sci. 74:2785-2802.

Sheperd, A. C., and D. K. Combs. 1998. Long-term effects of acetate and propionate on voluntary feed intake by midlactation cows. J. Dairy Sci. 81:2240-2250.

Storry, J. E., and J. A. F. Rook. 1965. Effects of intravenous infusions of acetate, $\beta$-hydroxybutyrate, triglyceride and other metabolites on the composition of the milk fat and blood in cows. Biochem. J. 97:879-886. 